\title{
Delivering a Simple Maize Maturity and Harvest Date Prediction Model
}

\section{Matthew Laurenson, Seishi Ninomiya}

National Agriculture Research Center, Kannondai 3-1-1 Tsukuba shi, Ibaraki 305-8666, JAPAN

\begin{abstract}
This paper describes an operational implementation of a simple model to assist with maize variety selection and harvest data prediction, using personal computer (PC) relational database software. The three-stage growing-degree model uses daily weather data and any current season field observations of silking and maturity to predict physiological maturity and harvest date. Thirty years of historical data are used to estimate the expected harvest date and its variation, and explore the risk of frosts prior to crop maturity. A grain procurement company used the software over several seasons to advise its clients, and the software was extensively revised over this period.

Experience with this single crop, PC-based, monolingual system has led us to embark on the development of a new multi-crop, Internet-based, multilingual system. A number of elements of the new system have been completed or prototyped. Its key concepts include the use of a mediated architecture, centralised object-oriented databases, and Internet-based mapping software.
\end{abstract}

\section{Keywords}

Java, object-oriented databases, weather, crop models, GIS, Internet, multilingual

\section{Introduction}

Maize is grown as a summer crop in the North Island of New Zealand for use as an animal feed (particularly for poultry) and in snack foods. One of the main production risks is of a killing frost of $-2{ }^{\circ} \mathrm{C}$ or colder occurring before the crop has reached physiological maturity. Higher yielding varieties take longer to mature, so farmers trade off yield and risk in selecting which variety to grow.

This paper describes a software system "Corn Planting Manager" developed and refined over several seasons in the mid 1990s in New Zealand to assist maize growers with variety selection and predict harvest dates. This software was developed using PC relational database software, with Internet links for weather data acquisition.

\section{Method}

Corn seed companies use Comparative Relative Maturity (CRM) figures to describe their hybrids. CRMs represent the number of heat units required by each variety to reach maturity. Based on their knowledge of local climate, and on their own and others' experience, growers can choose varieties with various CRMs to spread the harvesting or sowing period, and reduce the risk of crop loss through frost. While CRMs give the farmers a feeling for the relative maturation rates 
of different hybrids, it is helpful for them to know what the approximate harvest date will be if they plant a particular hybrid on their own farm. A weather-based phenological model can provide this kind of prediction.

Work in New Zealand suggested that the threshold temperature used for CRMs in the United States was inappropriate for New Zealand's more temperate climate. Corn Planting Manager uses a simple three-stage Growing Degree Day (GDD) model based on daily maximum and minimum temperatures to predict maize development. This model has been validated for several maize varieties in the New Zealand North Island (Hardacre, Brooking, and Sinclair 1992). GDDs in the model are calculated by averaging each day's maximum and minimum temperature, and accumulating any positive difference between the average temperature and a growth stage-specific temperature threshold. The growth stages and their temperature thresholds are shown in Table 1.
Table 1 Stages used to model corn growth and their threshold temperatures

\begin{tabular}{ll}
\hline Growth Stage & Threshold Temperature \\
\hline Sowing to Silking & $8^{\circ} \mathrm{C}$ \\
Silking to Maturity & $0^{\circ} \mathrm{C}$ \\
Maturity to Harvest & $0^{\circ} \mathrm{C}$ \\
\hline
\end{tabular}

The model accumulates GDDs within a growth stage until it reaches the requisite number for the stage (the stage "target"), at which point it switches to the next developmental stage and begins accumulating GDDs using the new stage's threshold temperature. Stage targets are hybrid specific, for example the Pioneer ${ }^{\circledR}$ hybrid P3751 requires approximately $660 \mathrm{GDDs}$ to reach sowing from silking (at a base of $8{ }^{\circ} \mathrm{C}$ ), 1300 GDDs (base $0{ }^{\circ} \mathrm{C}$ ) from silking to reach physiological maturity, and a further 500 GDDs (base $0{ }^{\circ} \mathrm{C}$ ) for the moisture level to reduce sufficiently for harvesting.

The model and its associated databases were implemented using the relational database Borland Paradox version 4.5, and its programming language ObjectPAL. ObjectPAL is a rich event-driven

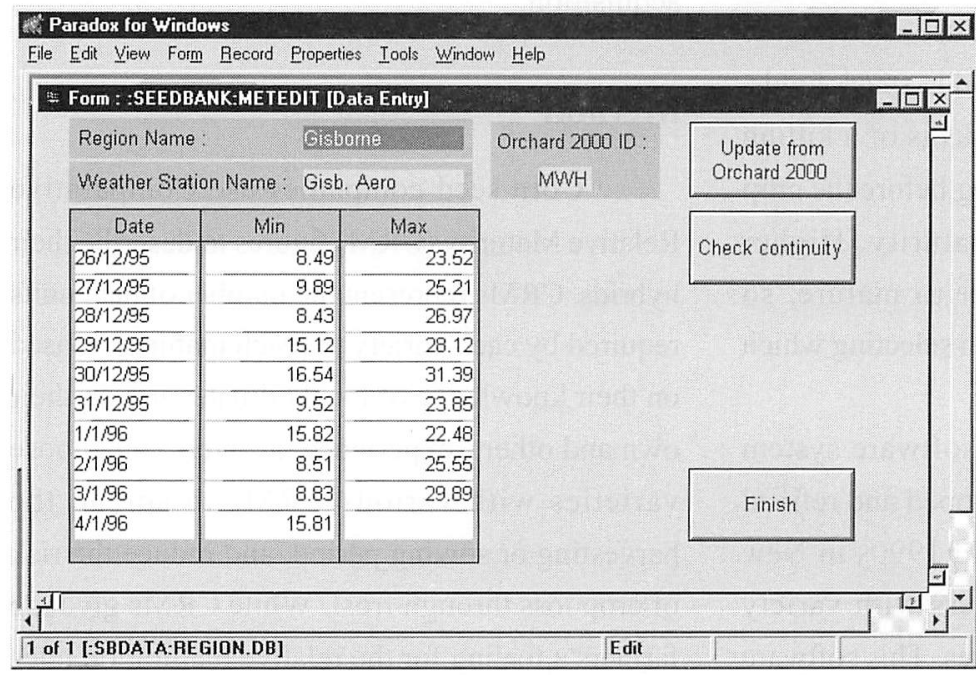

Figure 1

Weather data entry screen. 
programming language. Although it lacks features of object-oriented languages such as inheritance and the ability to define new software classes it is well suited to database software development. Being an interpreted language it is rather slow, but its excellent connectivity to other databases allows for rapid software development.

Daily minimum and maximum temperatures for 30 years from the New Zealand National Climate Database (Penney 1997) were used as the historical weather input (Figure 1). Contiguous data series were developed by identifying one currently operating weather station as the primary source for a region, and then filling any gaps by using data from one or more nearby stations. Maximum temperature data from other stations were adjusted by adding the averaged difference between the maximum temperatures recorded at both stations for all days for which data at both stations were available. Minimum temperatures were adjusted in a similar way. This process was repeated using progressively more distant stations until a contiguous data set was obtained. Paradox's connection to Oracle SQL-Net was used to develop an automatic updating mechanism to refresh the local copy of the data from the National Climate Database.

The model can either be run using historical weather data only ("winter mode"), or in the middle of the growing season ("summer

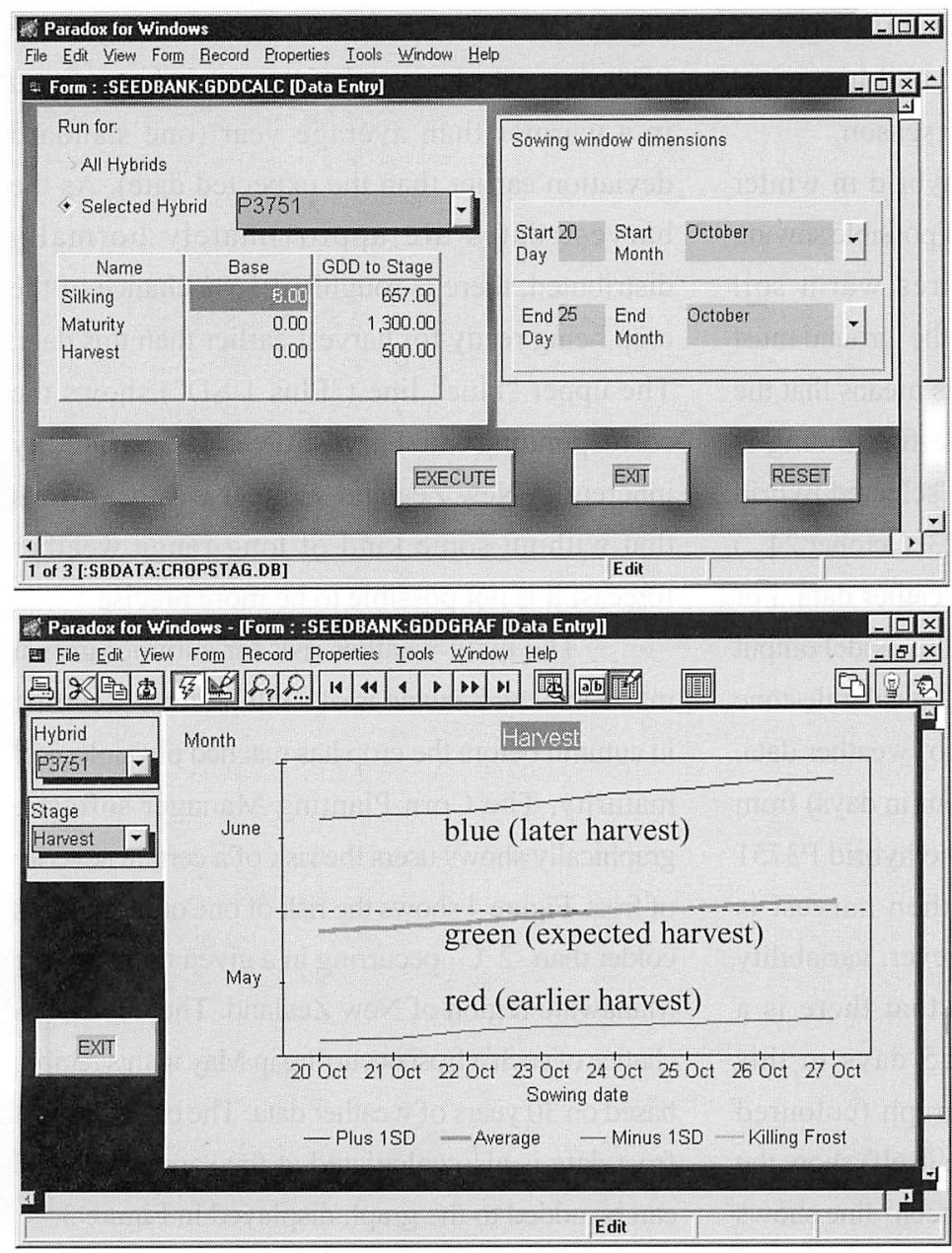

Figure 2

Hybrid-specific parameters.

Figure 3

Expected harvest date and variation. 


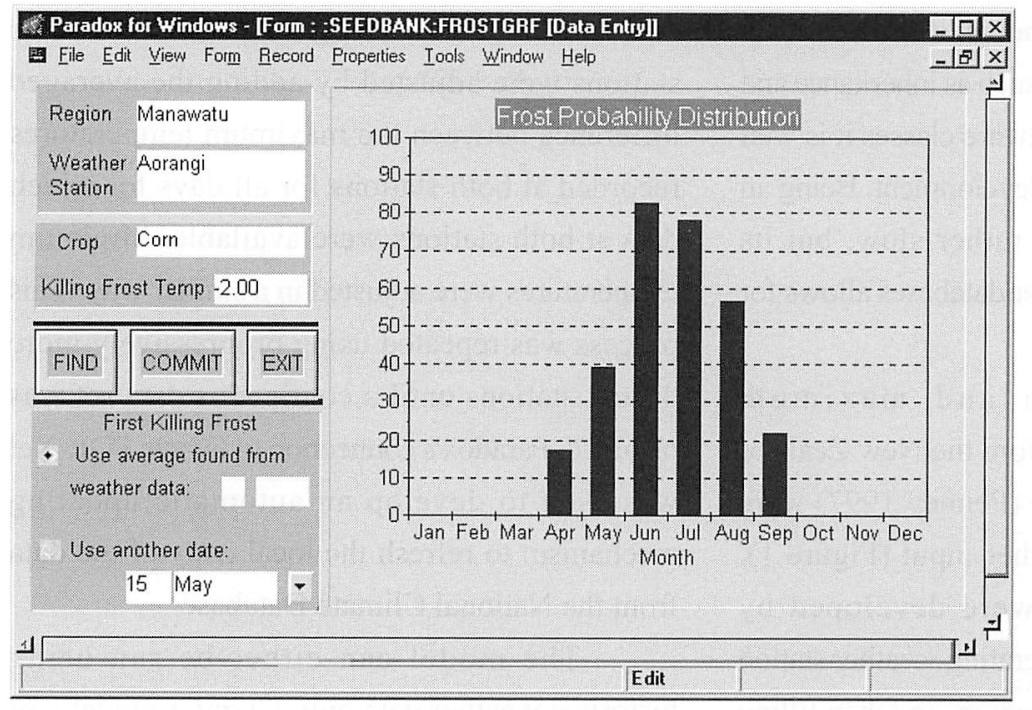

Figure 4

Frost risk by month in the southern North Island of New Zealand. mode") by using observations of crop development milestones like silking and maturity, weather data to date, and historical weather for the remainder of the season.

To evaluate a potential hybrid in winter mode, the user selects an interval of possible sowing dates (Figure 2). Maize requires warm soil temperatures for germination, and the ground must be dry enough for machinery. This means that the user's choice of the starting date for sowing is limited. The model is run for the selected hybrid for each sowing date (eg October 23, October 24...) in the interval, for each year of weather data. For each sowing date (eg October 23) the model output is the average date that each phenological milestone is reached over the 30 years or so of weather data, together with the standard deviation (in days) from that date. Figure 3 shows that if the hybrid P3751 is planted around October 24 then harvest is expected at the end of May. However, variability inherent in the weather means that there is a standard deviation of around 25 days in this prediction. Three lines on the graph (coloured green, blue and red in the software itself) show the mean and variation. The central "green" line shows the expected harvest date (labelled Average in Figure 4). The lower "red" line (labelled "Minus 1 SD") shows the harvest date that might be expected in a warmer than average year (one standard deviation earlier than the expected date). As the harvest dates are approximately normally distributed, there is roughly a $16 \%$ chance of the crop being ready for harvest earlier than this date. The upper "blue" line ("Plus 1 SD") shows the corresponding late harvest date. The variability inherent in New Zealand summer weather means that without some kind of long-range weather forecast it is not possible to be more precise.

The main weather risk for summer grown maize in New Zealand is of a killing frost occurring in autumn before the crop has reached physiological maturity. The Corn Planting Manager software graphically shows users the risk of a certain severity of frost. Figure 4 shows the risk of one or more frosts colder than $-2{ }^{\circ} \mathrm{C}$ occurring in a given month in the Manawatu region of New Zealand. There is a $40 \%$ chance of such a frost occurring in May in this region, based on 30 years of weather data. The expected first frost date is also calculated at the same time, and can be added to the graph displayed in Figure 3. 
Once a crop is planted there is no longer any choice of sowing date or variety, and the focus shifts to predicting the harvest date for logistical planning (Figure 5). The model stores details of the plantings such as the sowing date, nearest weather station, and any observation of developmental milestones (the "Actual" column in the lower middle of the screen). These observations, together with the actual weather data for the growing season to date are used by the system to improve the accuracy of its harvest date estimates and reduce uncertainty. The "Typical" column in Figure 5 holds 30-year averages for this sowing date. The "Mean" figures show the expected maturity and harvest dates this year. It can be seen from the "Minus 1SD" and "Plus 1SD" columns that the uncertainty in the harvest date has now reduced to only four days, compared with around 25 days at the beginning of the season.

This information is also presented graphically in the model (Figure 6). This software screen is somewhat complex, and uses colour to convey information, so it is also represented diagrammatically in Figure 7. When the model is run for a particular planting, any actual weather
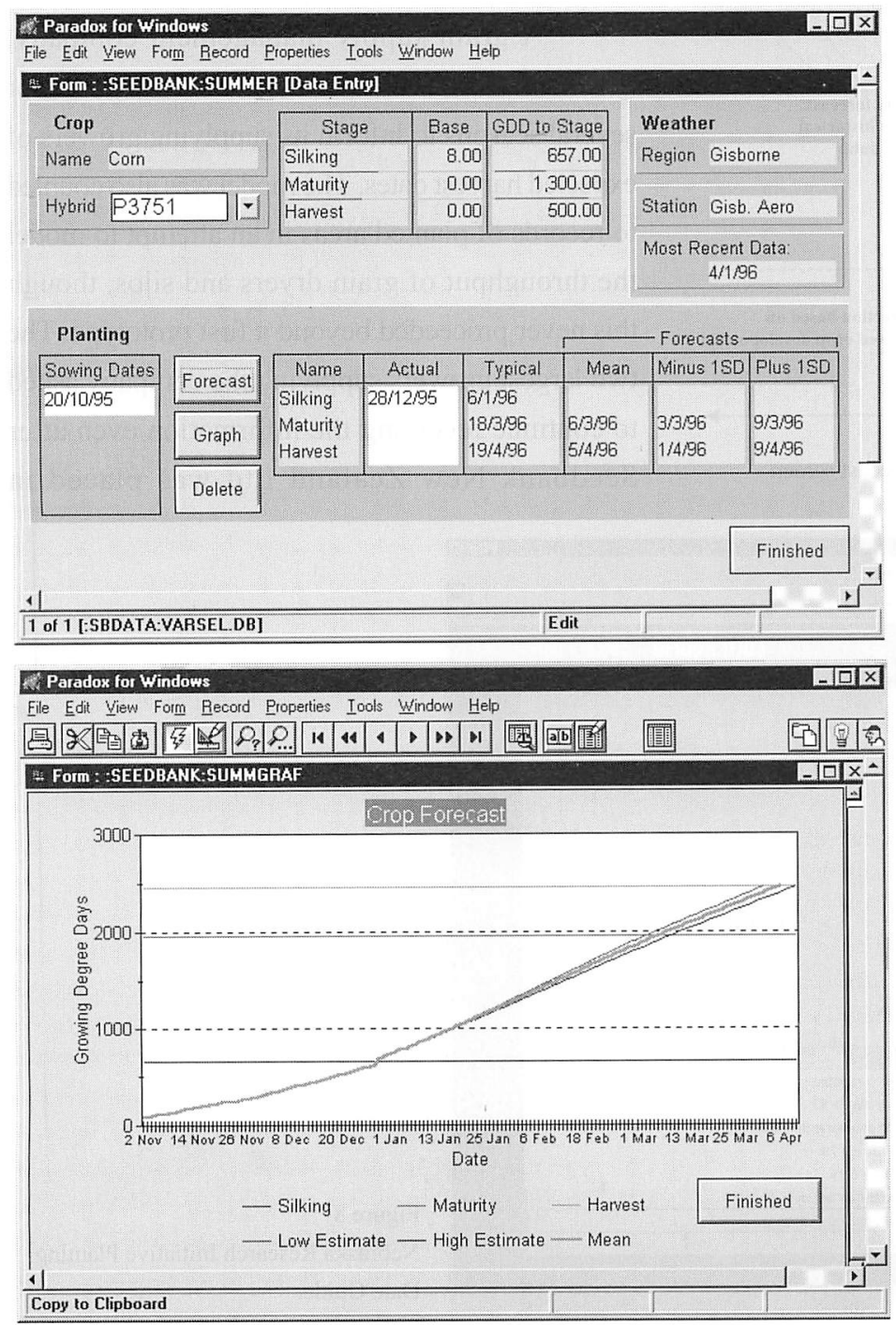

Figure 5

Harvest date forecasting in mid summer - textual information.
Figure 6

Harvest date forecasting in mid summer - graphical view. 
data available for the season is used initially (the left-hand side of the graph in Figure 6). Any growth stage observations that have been entered for the planting are used to correct the model's stage predictions. The discontinuity at silking is an example of this kind of adjustment. Historical weather is used to run the model for the remainder of the season as a proxy for forecast weather. The model uses each historical year's data in turn to run through to harvest. In warmer seasons, the crop can be harvested earlier, and in cooler seasons

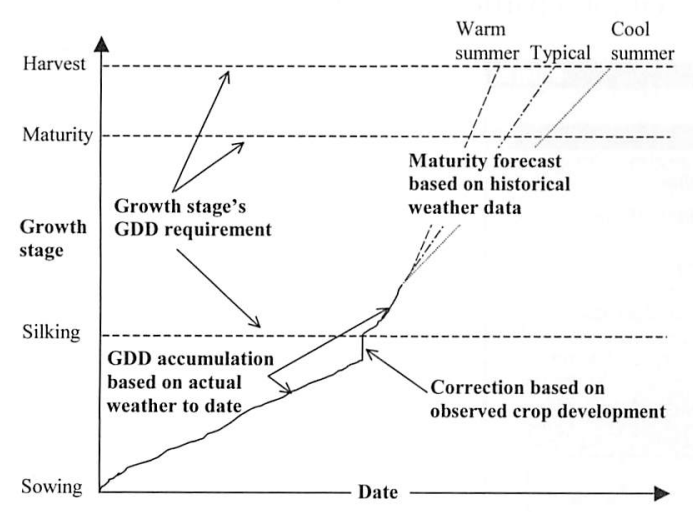

Figure 7 Guide to the summer forecast screen. harvest is delayed. The three diagonal lines on the right hand side of the graph indicate the range of expected harvest dates by their intersection with the harvest GDD threshold. The middle of the three lines corresponds to the expected harvest date. The shallower line shows the time to harvest in cooler years (one standard deviation) and the steeper line showing the result in warmer years. As the season progresses, the splay in these lines is progressively reduced.

\section{Results and Discussion}

A grain supply management company, Seedbank New Zealand Ltd, used this software for several seasons to inform its supplying growers of expected harvest dates. The model was also coupled to records of planted areas in an attempt to model the throughput of grain dryers and silos, though this never proceeded beyond a first prototype. The two largest growers supplying the company asked to continue receiving the information even after Seedbank New Zealand Ltd was placed in

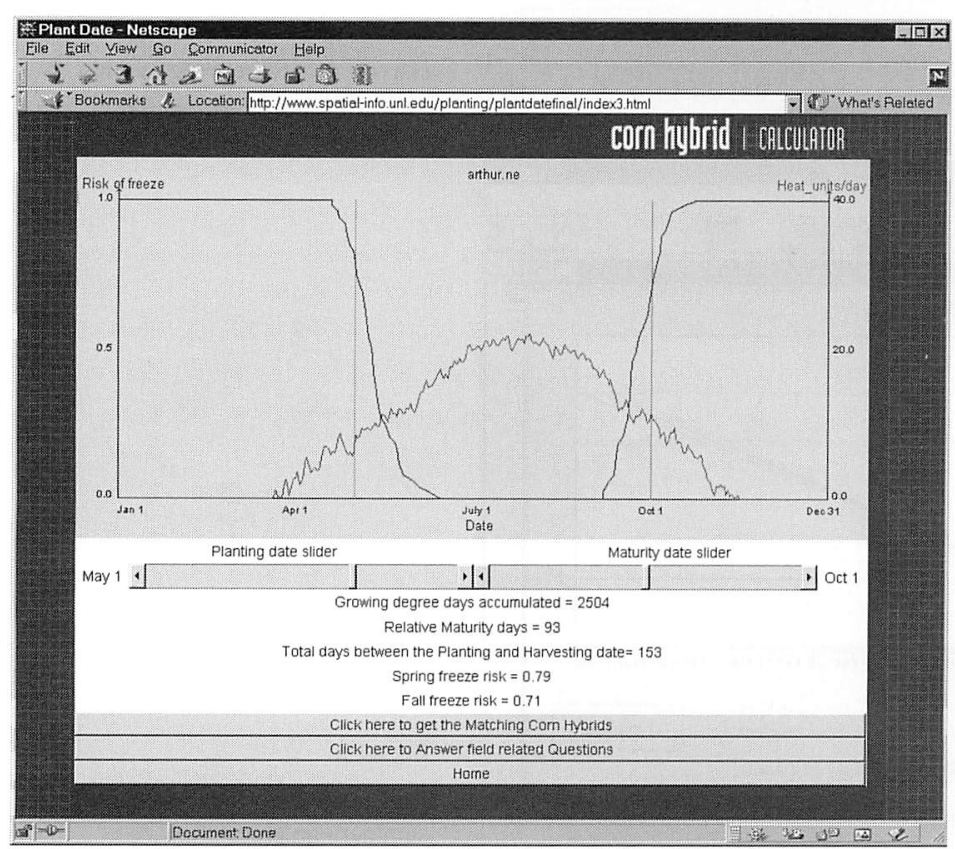

Figure 8

Nebraska Research Initiative Planting Date Guide. 
receivership, and a competing supply management company has now developed software with similar functionality. Corn Planting Manager was also used on behalf of another company to examine the benefits of distributing plantings of sweet corn over several climatic regions.

Experience with Corn Planting Manager, and with another weather-based decision support system, Orchard 2000 (Laurenson, Buwalda, and Walker 1994) convinced us that there were significant costs involved in deploying PC-based software. Much of the data used in agricultural models is common to multiple users. Examples include weather data, agrichemical details, crop varieties and model parameters. It makes sense to maintain these data centrally, rather than require that each user maintain their own copy.

Centrally storing details of farm management units and linked farm records also facilitates their backup, an aspect that is often neglected in smaller businesses. By locating software centrally, installation difficulties are largely avoided, and the software can be easily updated and supported. Larger agricultural businesses usually have IT professionals who can easily assist with support but farmers sometimes do not have the basic computer skills required. It doesn't make economic sense for the farmer to take the time to develop those skills, for their ability to retain them through repeated use is limited (Kuhlmann 1999).

The Internet offers a new way to deliver crop models to growers, and many organisations have used it to deliver agricultural models (Georgiev 1999), (Coop 2000). One example of particular relevance is the Planting Date Guide developed under the Nebraska Research Initiative (Nebraska Educational Telecommunications 2000). This lets users zoom in to their farm by choosing the general area from a digital terrain model of the state, then from a LandSat image of the county. Users then draw an outline of their field with an aerial photograph as the backdrop. The system selects the nearest weather station and shows a graph of frost risk and heat unit accumulation (Figure 8). If the user provides further information on their past cropping, the system can also make variety recommendations. The system currently provides information for corn growers, and a soybean module is also planned. Two apparent limitations of this system are that it is tied to a particular weather data set, and that user-entered data is not accessible to the user on subsequent site visits (though it can be stored for research use).

Figure 9 shows a new system currently under development at the National Agricultural Research Center. It consists of existing systems like MetBroker (Laurenson, Kiura, and Ninomiya 2000), prototyped elements such as the SimCrop applet, FarmDB and CropBroker, and some modules that have not yet been developed like the Thesaurus Broker. In general, the modules are separate applications each running on a separate computer. The modules communicate with one another over the Internet using the Java Remote Method Invocation (RMI) protocol for distributed computing. The system uses a mediated

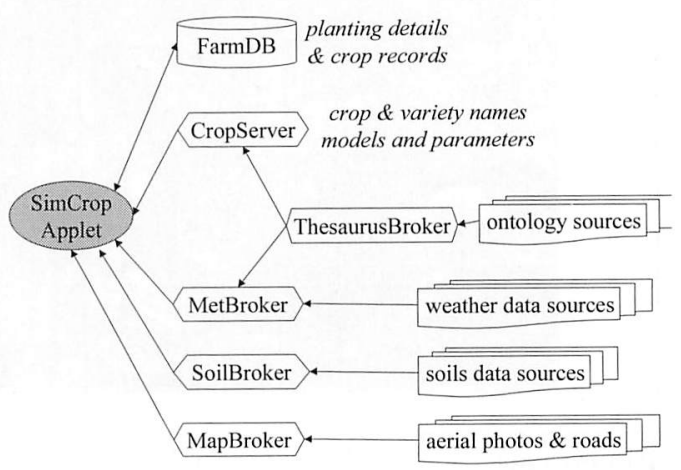

Figure 9 SimCrop structure. 
architecture (Wiederhold 1992) to manage its heterogeneous set of data sources.

The roles of the modules are as follows: FarmDB stores user inputs such as farm and planting details, and crop records. CropServer provides general crop information in the user's preferred language, like lists of crops, varieties of those crops, and growth stages. It also provides models for predicting growth stages such as harvest date. MetBroker provides a consistent interface to the weather data required by the CropBroker models. An operational version of MetBroker currently provides access to eight online databases in five countries, and its performance encourages us that the distributed computing approach is feasible. All three modules have been implemented using an objectoriented database, ObjectStore PSEPro 6.0.

ThesaurusBroker is internded to provide ontology and multilingual services to domainspecific brokers. It would support concepts such as "broader term", "narrower term", and "related term". For example, if CropBroker needed to provide a list of crops to a user in Japan, it might establish a Japanese language session with ThesaurusBroker and ask for a list of narrower terms for "crops". Similarly, to get a list of variety names for daikon, CropBroker might ask ThesaurusBroker for a list of narrower terms for "daikon".

\begin{tabular}{|c|c|c|}
\hline EimCrop Applet & yersion - Microsolt Internet Explorer & $-\square[x$ \\
\hline f File Édit Yier & Fagvorites Iools Help & 49 \\
\hline$\underset{\text { Back }}{\stackrel{4}{4}} \quad$ " & Address 4 hittp://ume narc. affrc. go.jp/ matthewl/simCrop Applet. html & $\rho G_{0}$ \\
\hline
\end{tabular}

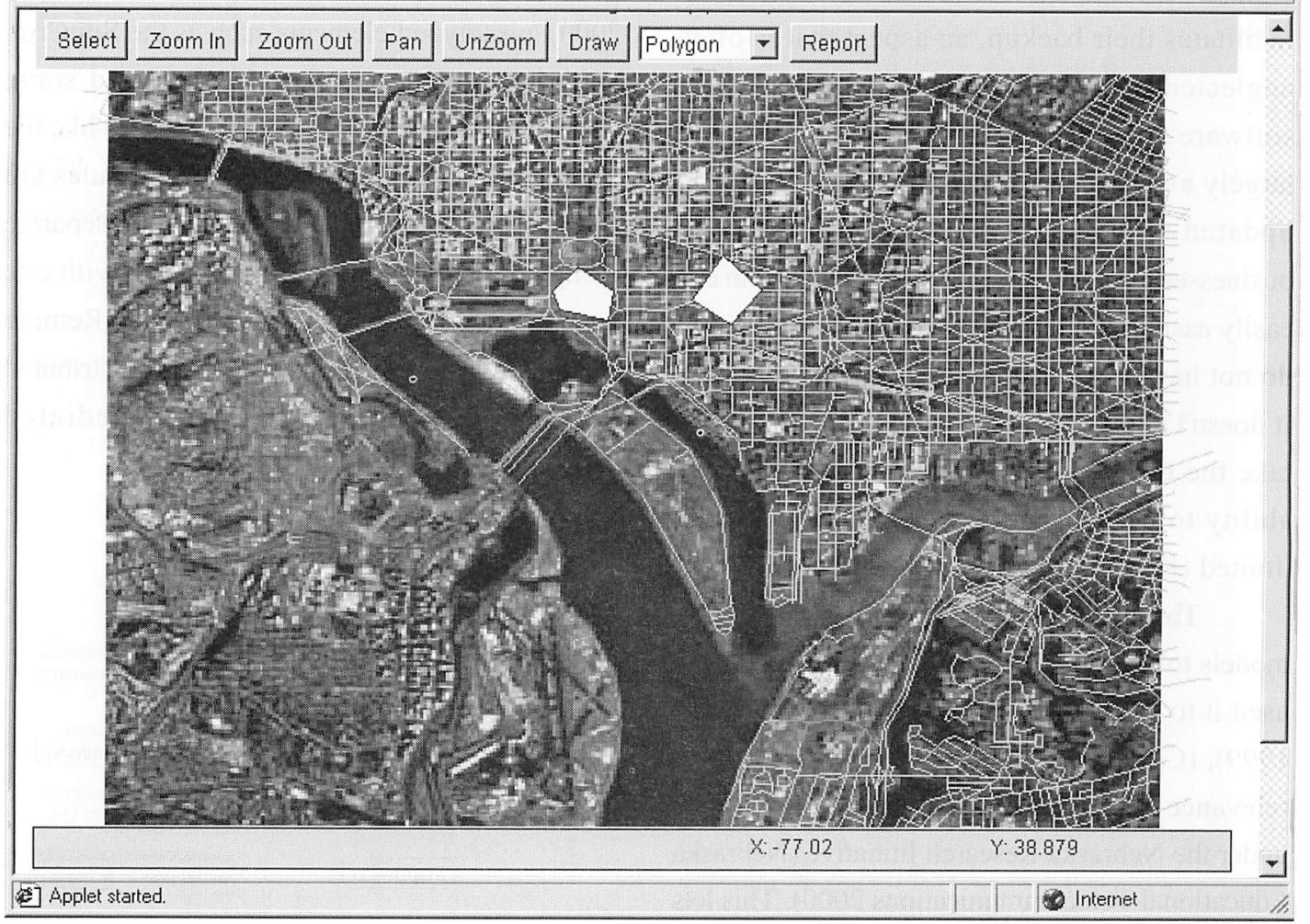

Figure 10 SimCrop prototype user interface. 
Development of SoilBroker has recently commenced. It will provide soils data from various online databases. MapBroker has not yet been developed, but would provide applications with aerial photographs and road data from various online data sources. The SimCrop applet would let users record crop plantings against a background aerial photograph and road map, and run models to predict harvest dates. A prototype that uses a single aerial photograph and road map is shown in Figure 10. The applet uses the ActiveMaps class library from InternetGIS.

Users running the applet are prompted for a user code and password. The applet then retrieves their own planting details from the central database, and displays the fields on a map. The user can create a new field, or select an existing field and delete it or edit the associated details. The details recorded for each field are shown in Figure 11. The prototype does not yet allow models to be run using these details.

The main advantage of the centralised approach advocated is that the costs of operating and supporting the system are shared among users. Their data is stored securely in a central database, so they can run the system from any Internet-enabled computer that they own, be it a wireless-linked laptop or their office computer. There is no need for the user to install the software or back up their data. By using Java applets as the software delivery mechanism, software installation and updating is relatively transparent. The latest copy of the client-side software is cached on users' machines, and if an update is available it is automatically downloaded to replace the cached version. Farmers must still enter their field data, but it can be backed up en masse and restructured if necessary.

There are several technical barriers to this approach. The first is that most growers currently on the Internet use a dial-up connection limited to around $3 \mathrm{~KB}$ per second. Over this kind of connection the prototype applet takes several minutes to load, in part because the road network and associated details occupy around 750KB. (In comparison, the underlying aerial photograph only occupies $36 \mathrm{~KB}$ ). It may be possible to reduce the bandwidth requirements by more server side processing of the road network (eg only showing major roads at larger scales). New home Internet technologies like cable, ADSL and satellite also offer much higher bandwidth connections and most avoid tying up the household telephone line.

The second technical issue is that native browser support for Java 2 is limited to Netscape 6. Internet Explorer and older versions of Netscape require the Sun Java Plug-in in order to run the applet. This requires a 7.5 $\mathrm{MB}$ download, which might take an hour over a standard dial-up connection. At present, the Plug-in is intended to

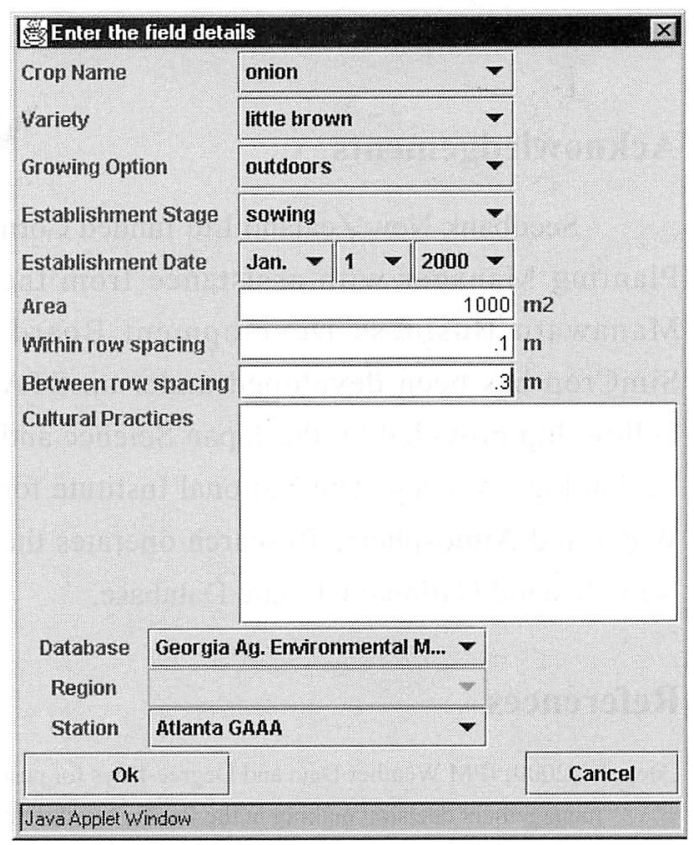

Figure 11 SimCrop field details. 
support corporate intranet users, rather than the general public. It would be possible to distribute the Plug-in on disk, but this negates some of the benefits of applets. New higher bandwidth home Internet technologies will help reduce the impact of this issue - for example over ADSL the Plug-in takes only a minute or so to download and install.

Some corporate users of RMI have had difficulties with organisational firewalls blocking the RMI communications, because RMI uses unusual ports. While this can usually be addressed with changes to firewall settings, this kind of operational problem can severely hamper uptake of a new system.

The other major issue is not technical but psychological. Users of minicomputers and mainframes welcomed PCs because it gave them control over their computing environment. Users of the new system will need to be convinced of the security of their data, of the reliability and longevity of the system, and of the benefits of better harvest predictions and other information before committing precious time to data entry.

\section{Acknowledgements}

Seedbank New Zealand Ltd funded Corn Planting Manager with assistance from the Manawatu Business Development Board. SimCrop has been developed under an STA Fellowship provided by the Japan Science and Technology Agency. The National Institute for Water and Atmospheric Research operates the New Zealand National Climate Database.

\section{References}

Coop, L. (2000) IPM Weather Data and Degree-Days for pest management decision making in the Pacific Northwest [web page]. 5 June 20002000 [cited June 26 2000].
Available from http://osu.orst.edu/dept/ippc/wea/.

Georgiev, G. (1999) Crop Simulation Model [web-based application]. Georgia Automated Environmental Monitoring Network, November 11, 19991999 [cited 11 November 1999]. Available from http://www.griffin. peachnet.edu/bae/simulation.html.

Hardacre, A. K., I. R. Brooking, and K. I. Sinclair. (1992) Maize and the weather in the Manawatu. Palmerston North, New Zealand.

Kuhlmann, F. (1999) Farm-Level-Information-Systems: Developments and Perspectives. In Proc. 2nd European Conference of the European Federation for Information Technology in Agriculture, Food, and the Environment, 7-17, Bonn; Germany.

Laurenson, M., T. Kiura, and S. Ninomiya. (2000) Accessing online weather databases from Java. In Proc. Internet Workshop 2000, 193-198, Tsukuba, Japan.

Laurenson, M. R., J. G. Buwalda, and J. T. S. Walker. (1994) A decision support system for New Zealand's orchard industries. NZ Journal of Crop and Horticultural Science 3:239-250.

Nebraska Educational Telecommunications. (2000) Planting Date Guide [web-based model]. Nebraska Research Initiative, September 15, 20002000 [cited November 24 2000]. Available from http://www.spatialinfo.unl.edu/planting/.

Penney, A. C. 1997. Climate database (CLIDB) user's manual. Wellington, New Zealand: The National Institute of Water and Atmospheric Research.

Wiederhold, G. 1992. Mediators in the architecture of future information systems. IEEE Computer 25(3):38-49. 


\title{
トウモロコシ簡易登熟期・収穫期予測モデルの \\ 開発と普及
}

\author{
Matthew Laurenson・二宮正士 \\ 独立行政法人・農業技術研究機構・中央農業総合研究センター \\ 干 305-8666 茨城県つくば市観音台 3-1-1
}

\section{要旨}

トウモロコシ品種の選定や収穫期予測を支援するための簡易モデルをパソコン上のリレー ショナル・データベース・ソフトウエアを活用して開発し実際に運用した。実装したのは 3 段階の生育ステージに基づくモデルで, 毎日の気象データと絹系抽出期や登熟期に関す る围場観察から収穫日等を推定するものである．その際，30 年間にわたり蓄積されたデー 夕を使って, 平均収穫日やその変動幅を推定したり, 登熟に先立つ霜害の危険性を予測で きる．穀物買上会社は，何年にも渡り，本ソフトウエアを利用して，農家を指導してきた． その間平行して, 本ソフトウェアを大幅に見直し改良も行った.

このパソコン上の英語版単一作物モデルを開発し運用する経験から，インターネット上 で複数作物を扱える多言語システムの開発の必要性を痛感するようになった．そして，そ のための全く新しいシステム開発に着手し, 相当部分が開発終了したり, プロトタイプと して実現できた. 新システムの基本概念は, データの仲介システム, オブジェクト指向デー タベース, インターネット対応の地理情報ソフトウエアである.

キーワード : Java, オブジェクト指向データベース, 気象, 作物モデル, GIS, インターネット, 多言語 